\title{
Success Factors, Enablers and Barriers in Social Projects: \\ A Literature Review
}

Mariana Voros Fregolente (mariana.fregolente@usp.br) - Polytechnic School, University of São Paulo (USP).

Marly Monteiro de Carvalho (

\begin{abstract}
The authors conducted a systematic literature review of articles that described projects focused on resolving social issues, frequently associated with the terms base/bottom of the pyramid (BoP), social entrepreneurship and social innovation. Projects are classified accordingly to the source of the idea (top down or bottom up) and the project type (commercial, creative, assistance, collaboration, entrepreneurial or cooperative). They are also compared considering target population, socio-economic context, geography, motivation, critical success factors (CSF), enablers and barriers. The results indicate that most projects are top down, creative or commercial, connected to social innovation or social entrepreneurship approaches, implemented on European countries, aiming at solving local issues related to the management of rural and urban territories, healthcare, education or energy. The themes mostly associated with social projects are territory management and transition to renewable energies. BoP-related projects are almost inexistent, and so are projects aiming at povertyrelated issues. Nonetheless, the CSF encountered in these projects are very similar to the ones reported in BoP literature, mainly including legitimacy with local communities, network building, strategic partnerships, development of local capabilities, and access to resources financial, technological, human and material.
\end{abstract}

Keywords: Base of the pyramid, bottom of the pyramid, social innovation, social entrepreneurship, poverty 


\section{INTRODUCTION}

Projects are suited to achieve agility and innovation (Prouska \& Kapsali, 2020). Projects and business ventures that aim at solving social problems suffer the pressure of getting more done with less, acting in contexts poor in resources and knowledge, where small-scale incremental projects are suited to creating economic value while also addressing social and environmental issues (Galdini, 2020; Malsch \& Guieu, 2019). Therefore, this context seems appropriate for the flourishment of projectified logics aiming at solving social problems, some of them related to 'bottom or base of the pyramid' (BoP) issues.

Social innovation and social entrepreneurship theoretical streams are frequently associated with social problems' solutions. Nonetheless, social entrepreneurship is more associated with sustainability projects - energy sources, farming technologies, and waste management - and to business models. Social innovation, with urban regeneration, rural development and solution of community-related issues through social design and participatory design.

Despite the potential for generating solutions for untapped market segments, social projects frequently fail to achieve their objectives. This article aims to analyze projects designed to solve social problems to obtain a better understanding of the reasons that explain their success or failure, paving the way to avoid common pitfalls and increase social projects' success rate. Contributions for the practice include a presentation of CSF and enablers that contribute in overcoming challenges encountered in social projects. Contributions for the theory includes the analysis of different theoretical perspectives that have been applied in similar contexts.

\section{LITERATURE REVIEW}

\subsection{Bottom/Base of the Pyramid (BoP)}

BoP refers to the bottom-tier of the world income pyramid, a cross-national class of population living in a situation of extreme or moderate poverty (Gold et al., 2013; Hahn, 2009; Sharma \& Jaiswal, 2018), residing primarily in urban slums, semi-urban and rural areas, living and transacting in an informal economy, and lacking access to mechanisms for the fulfilment of basic human needs (Goyal et al., 2020; Prahalad \& Hart, 1999; Viswanathan \& Sridharan, 2012).

It is often associated with different strategies to alleviate global poverty. The most common one advocates the application of a market logic, with the engagement of the private sector to transform the poor into consumers of products and services to which they are currently 
underserved, exploring the potential of profitable segments in this largely untapped market, while simultaneously contributing to the development of local economies and to the resolution of significant societal problems in these regions (Hahn, 2009; Olsen \& Boxenbaum, 2009; Seuring et al., 2019; Viswanathan \& Sridharan, 2012).

The interest on designing business ventures to serve the BoP is based on a mutual value creation perspective that advocates the possibility to generate profitability and provide social value to the communities served. Approaches may vary, with some initiatives focusing more on the development and selling of products, while others are more concerned with the development of business partnerships, regarding BoP population not only as consumers, but primarily as integrative parts of all segments of the value creation process (Hahn, 2009; Karnani, 2007; London et al., 2010).

An important feature of BoP approaches is a rationale that includes making a profit, and therefore the business model includes the generation of a revenue stream. Nonetheless, operating in BoP markets implicates facing constraints that are context-specific, mostly related to operating in informal sectors, that have not yet been experienced by multinational companies or outsiders trying to enter these markets. These contexts pose real challenges to social ventures, and few companies have succeeded in implementing them. Thus, understanding and working on contextual constraints is critical for their success (London et al., 2010; Olsen \& Boxenbaum, 2009; Reficco \& Márquez, 2012).

\subsection{Social Entrepreneurship and Social Innovation}

Social entrepreneurship integrates economic and social value creation (Mair \& Martí, 2006). Social entrepreneurs differentiate themselves from commercial entrepreneurs through the adoption of business models that offer creative solutions to complex and persistent social problems, exploiting opportunities to enhance social wealth by creating new ventures or managing existing organizations in an innovative manner (Austin et al., 2006; Zahra et al., 2009).

Although the economic value is crucial for the sustainability of social entrepreneurial ventures (Dacin et al., 2011), the central driver for social entrepreneurship is the social problem being addressed (Austin et al., 2006). Therefore, local entrepreneurs and cooperatives are also considered capable of mutual value creation within the BoP, posing as an alternative solution to enhance life conditions when they manage to combine commercial enterprises with social 
impacts through the creation of enterprises that accomplish social purposes, in addition to being commercially viable (Alvord et al., 2004; Seuring et al., 2019).

Another strategy to approach the socio-economic issues related to BoP population is the use of social innovation tools - through the development of public policies or fostering the development of novel social forms and competitive advantages that promote social inclusion and improvement in living conditions (Bevilacqua \& Ou, 2018; Cazini \& Frasson, 2011; Gürdere Akdur \& Kaygan, 2019; Souza Costa et al., 2011).

The expression 'social innovation' refers to the use of new forms of collaboration - such as co-creation and co-production - to respond to challenges that are not being addressed through conventional approaches (Conrad, 2015). It is motivated by the goal of meeting a social need (Mulgan, 2006), and searches for a creative solution that will act on the roots of the social problems (Raynor, 2019) through the active involvement of social actors in the process, using of empowerment, fostering inclusion and wellbeing, and improving social relations to achieve the transformation of individuals themselves, changing the beliefs of the social system where the innovation occurs (Cox et al., 2014; De Filippi et al., 2017; Manzini \& Rizzo, 2011; Morelli et al., 2017; Souza Costa et al., 2011; Swagemakers et al., 2018).

\section{METHODOLOGY}

The sampling process was conducted in Web of Science (WoS) and Scopus databases due to the search mechanism capable to reach all indexed journals with an impact factor in the Journal Citation Report (JCR).

The research used the keyword "project" in the title, and the keywords "base of the pyramid" or "bottom of the pyramid" or "social entrepreneurship" or "social innovation" in the title, abstract or keywords. Only "articles", "reviews", and "early accesses" were included. All publications until November 2020 were included.

The search returned 53 papers from WoS, and 80 from Scopus. Their merge left the sample with 93 single papers. Titles and abstracts were analyzed, determining their alignment with research goals. The exclusion protocol included the reading of the whole paper for confirmation. Papers not written in English or unavailable were also excluded. As a result of the refinement process, 33 papers were excluded, leaving the sample with 61 articles. Figure 1 represents the complete sampling process. 


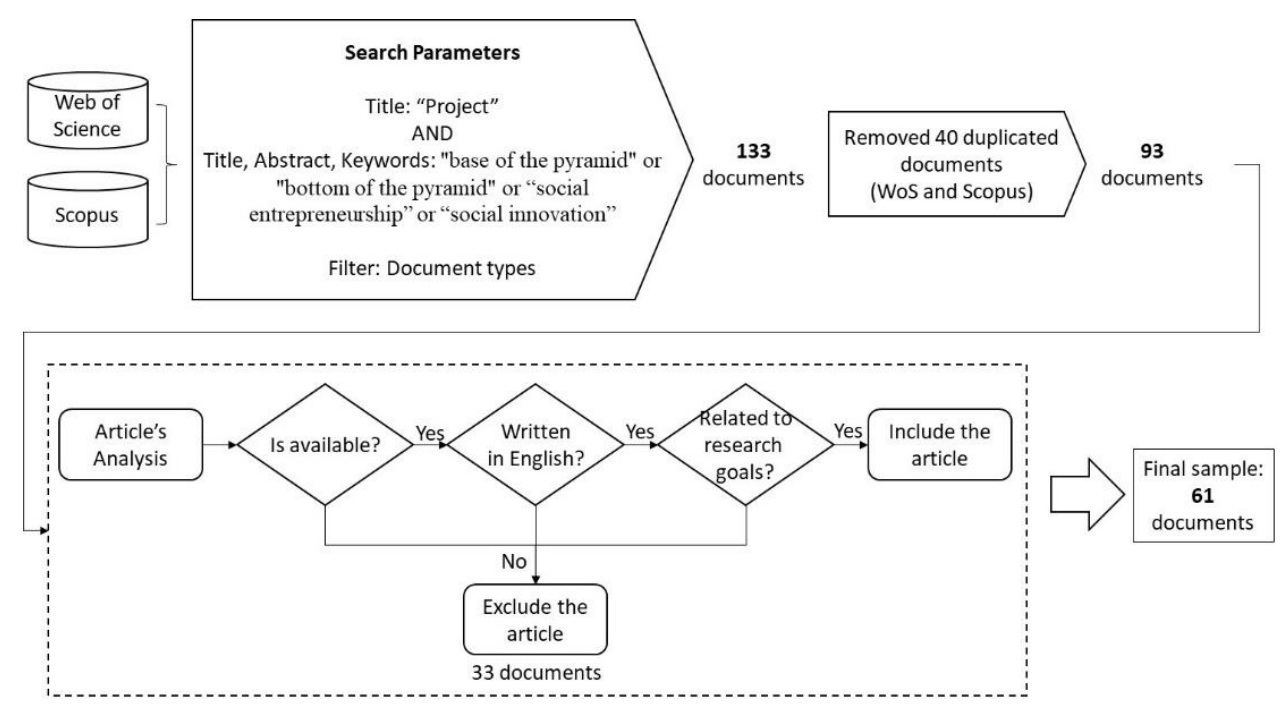

Figure 1. Sampling workflow

Keywords co-occurrence and reference co-citation analyzes were performed using VOS Viewer. A manual screening attributed codes using NVivo11, the abductive coding process applied following the coding cycles described by Skjott Linneberg \& Korsgaard (2019). A backward snowballing process included 84 articles in the literature review, but not in the systematic bibliographic review to avoid conflicts with research's goals.

\section{RESULTS AND DISCUSSION}

\subsection{Network Analysis}

The keywords co-occurrence analysis presented in Figure 2 indicates six different clusters. 


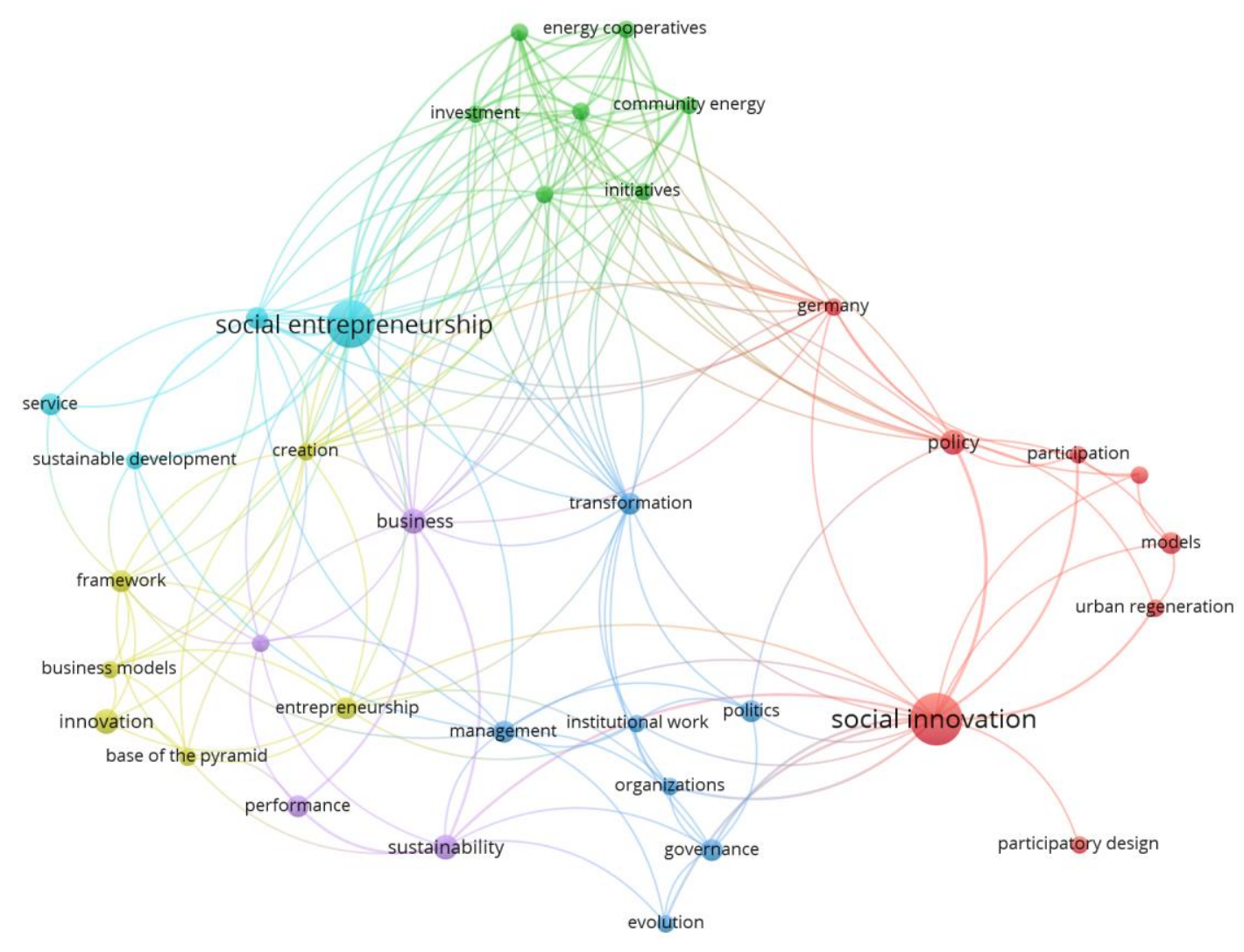

\& VOSviewer

Figure 2. Keywords co-occurrence analysis produced with VosViewer 1.6.15 using WoS bibliographic data

The co-citation analysis presented in Figure 3 indicates the existence of four groups. 


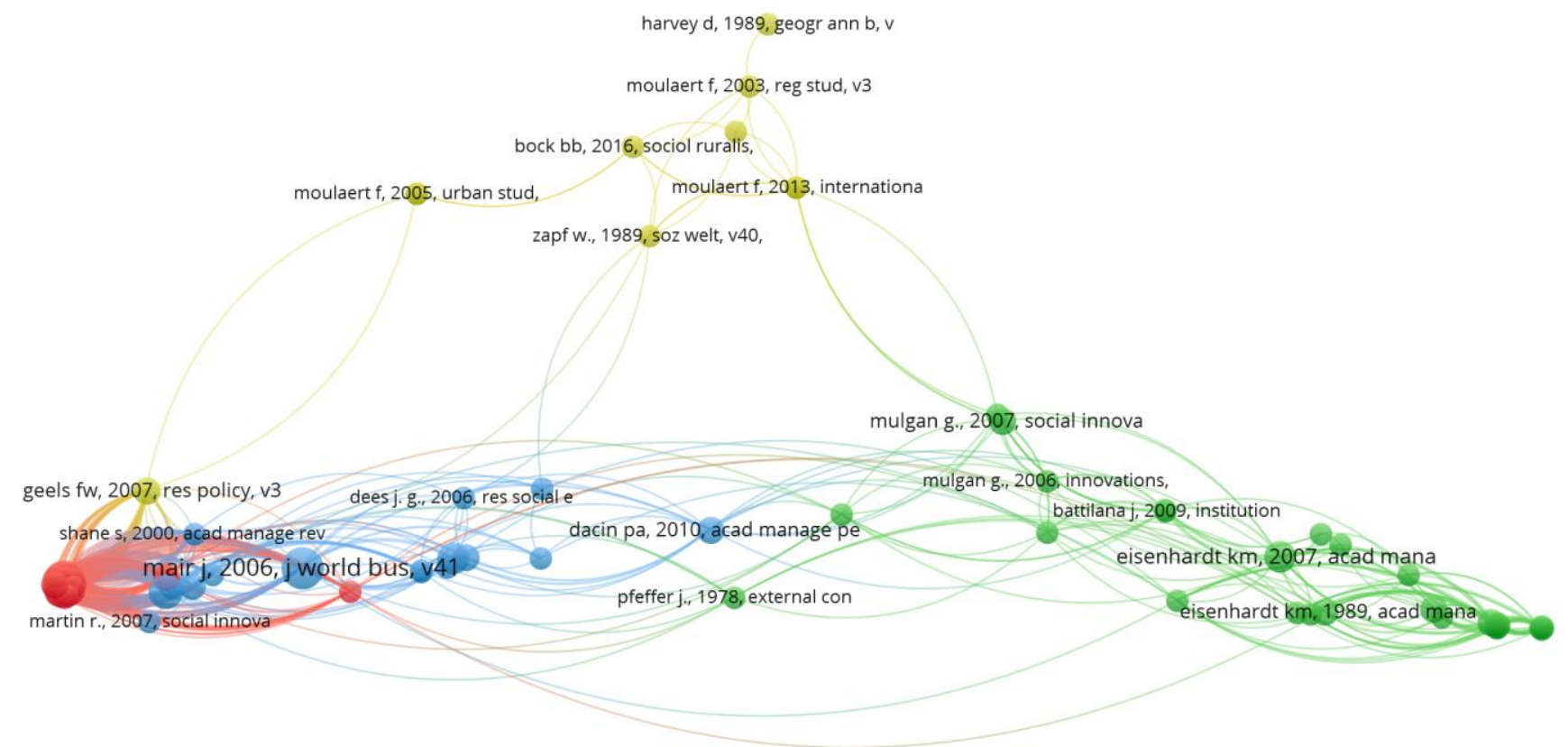

Figure 3. Co-citation analysis graphic produced with VosViewer 1.6.15 using WoS bibliographic data.

\subsection{Content Analysis}

The papers worked with case studies, using descriptive or qualitative approaches to provide an account of the projects - single projects being the most common analytic unit. Projects concerned with small regions are the most common ones, focused on resolving localized social problems. The existence of many international projects is explained by the abundance of projects funded by the European Union. Table 1 provides the complete results for the deductive coding process. 


\begin{tabular}{|l|r|}
\hline Research Method & \# of articles \\
\hline Case study & 39 \\
\hline Theoretical-conceptual & 9 \\
\hline Survey & 5 \\
\hline Action-research & 4 \\
\hline Modeling & 2 \\
\hline Experimental & 2 \\
\hline Approach & 34 \\
\hline Descriptive & 18 \\
\hline Qualitative & 7 \\
\hline Mixed & 2 \\
\hline Quantitative & \# of articles \\
\hline Sources of evidence & 16 \\
\hline public data & 11 \\
\hline Interview & 6 \\
\hline Questionnaire & \# of articles \\
\hline Bibliography & 5 \\
\hline document analysis & 4 \\
\hline press information & 1 \\
\hline Multiple & 18 \\
\hline Analytic Unit & 27 \\
\hline Groups/ projects & 18 \\
\hline Persons & \# of articles \\
\hline Companies & \# \\
\hline Government & of articles \\
\hline Geographic Scope & 2 \\
\hline Regional & 2 \\
\hline International & 2 \\
\hline National & 2 \\
\hline & 2 \\
\hline
\end{tabular}

Table 1. Deductive coding results

The abductive codes show a predominance of social innovation as a theoretical lens, followed by social entrepreneurship. Social groups were commonly defined as "local community". Projects were mainly implemented in European countries, aiming to solve problems related to aging population, urban deterioration and rural areas' development. BoP approaches were applied only to Asia, Africa and Latin America contexts. Additional codes that emerged from the coding process are represented in Table 2. 


\begin{tabular}{|c|c|c|c|c|}
\hline $\begin{array}{l}\text { Source of } \\
\text { Idea }\end{array}$ & Description & Project Type & Related Themes & Macro Objective \\
\hline \multirow{4}{*}{ Top Down } & \multirow{4}{*}{$\begin{array}{l}\text { Social groups as } \\
\text { receptors of ideas } \\
\text { coming from } \\
\text { external actors }\end{array}$} & Commercial & $\begin{array}{l}\text { Product or solution } \\
\text { development }\end{array}$ & $\begin{array}{l}\text { Profit from selling } \\
\text { solutions }\end{array}$ \\
\hline & & Creative & $\begin{array}{l}\text { Urban design, Social } \\
\text { design, Social learning, } \\
\text { Education }\end{array}$ & $\begin{array}{l}\text { Develop solutions with } \\
\text { the communities. Solve } \\
\text { collective problems in a } \\
\text { collective way }\end{array}$ \\
\hline & & Assistance & $\begin{array}{l}\text { Healthcare, age care, } \\
\text { housing provision, } \\
\text { people with } \\
\text { impairments, Civil } \\
\text { Society Organizations, } \\
\text { NGOs }\end{array}$ & $\begin{array}{l}\text { Provide assistance for } \\
\text { marginalized populations }\end{array}$ \\
\hline & & Collaboration & $\begin{array}{l}\text { Social shared value, } \\
\text { sustainable supply } \\
\text { chains }\end{array}$ & $\begin{array}{l}\text { Develop solutions that } \\
\text { address a corporation's } \\
\text { problems, but including } \\
\text { environmental and social } \\
\text { concerns during solution } \\
\text { development }\end{array}$ \\
\hline \multirow[b]{2}{*}{ Bottom Up } & \multirow{2}{*}{$\begin{array}{l}\text { Social groups or } \\
\text { individuals } \\
\text { creating and } \\
\text { implementing their } \\
\text { own ideas to solve } \\
\text { social problems }\end{array}$} & Entrepreneurial & $\begin{array}{l}\text { Single man/woman } \\
\text { solution, leaders }\end{array}$ & $\begin{array}{l}\text { Solve social problems in } \\
\text { a business way }\end{array}$ \\
\hline & & Cooperative & $\begin{array}{l}\text { Grouping entrepreneurs } \\
\text { or citizens with the same } \\
\text { problem }\end{array}$ & $\begin{array}{l}\text { Solve business problems } \\
\text { in a collective way }\end{array}$ \\
\hline Theoretical & $\begin{array}{l}\text { Explore concepts } \\
\text { concerning these } \\
\text { projects }\end{array}$ & All & $\begin{array}{l}\text { Knowledge } \\
\text { management, Project } \\
\text { management technics, } \\
\text { Design technics, } \\
\text { Frameworks, Project } \\
\text { tensions }\end{array}$ & $\begin{array}{l}\text { Understand the } \\
\text { underlying factors that } \\
\text { generate certain social or } \\
\text { economic dynamics }\end{array}$ \\
\hline Environmental & $\begin{array}{l}\text { Solve } \\
\text { environmental } \\
\text { related problems }\end{array}$ & All & Blue Economy & $\begin{array}{l}\text { Solve environmental } \\
\text { related problems }\end{array}$ \\
\hline
\end{tabular}

Table 2. Abductive coding for project origin and project type, and the relationships between these concepts

The source of idea is related to the origin factor of the project: from outsiders, like academia, government or companies, in a top-down way of dealing with the existing issues; or from the people affected by the problem, in a bottom-up way of self-organizing for the solution. Type is related to the project's approach solving the social issue targeted, and different sources of idea were directly connected to different project types.

Commercial projects address social issues commercializing solutions or products. Creative projects develop partnerships with local communities, both learning from and teaching the participants. Assistance projects result from public policies and provide solutions for marginalized populations or produce awareness around important collective issues. Collaboration projects address a corporation's problem through partnerships with local communities.

Entrepreneurial projects describe business ventures initiated by an entrepreneur from the affected community. Cooperative projects unite local entrepreneurs to create collective solutions to problems affecting them. 


\subsection{CSF and enablers}

Innovation is mentioned as a CSF for designing solutions capable of going beyond the constraints of the current situation. Since innovation implies experimentation, learning from failures, and validating hypotheses through repetitive processes, the importance of error tolerance is emphasized, as well as the inclusion of participants with diverse backgrounds, knowledge and expertise (Chou, 2018; Margarian, 2017; Martin de Holan et al., 2019; Navarro et al., 2018; Ochman, 2019; Raynor, 2019).

Credibility, trust, acceptance, and awareness from the communities involved are also CSFs. Their building includes a human centric design approach, a solution concerned with the improvement of human and social capital, and the development of win-win partnerships with stakeholders, collaborating for value-based creation, and enabling the economic development of local community as business partners (Goyal et al., 2020).

Community empowerment is a CSF related to the continuity of the projects, avoiding a lack of continuity that occur if local population remain as aid receivers instead of developing an entrepreneurial mindset fostered through business partnerships (Erözçelik \& Taşdizen, 2017; Kulick, 2017).

Business partnerships are not the only path to engage, though. Project results will also be optimized if the local community is included in the process of developing the solution, allowing real participation and influence in the design and in the decision-making processes. This approach also brings empowerment to the community, legitimacy to the project, builds trust amongst the actors involved, stimulates collective learning and minimizes power distortions. Local NGOs have a role in co-creating value, building trust based on long-term relationships at the BoP (Cox et al., 2014; De Filippi et al., 2017; Gold et al., 2013; Seuring et al., 2019; Ubels et al., 2019).

The importance of local communities includes a real understanding of their context and needs to align project scope with actual needs and limitations. Again, partnerships with local NGOs might work as crucial facilitators due to their unique insights into the local needs and constraints (Daub et al., 2020; Rampasso et al., 2020).

The existence of stable financial resources is another CSF because it promotes innovation and guarantees continuity. Funding might be captured through revenues or external resources and must sustain the enterprise in a way that is aligned with its proposal. It can be accessed through private or public institutions, or collaboration with available social networks although the dependence on external financing might lead to a competition for resources, 
which undermines the possibility of building cooperation networks (Ahlberg et al., 2016; Chang et al., 2014; Margarian, 2017; Ochman, 2019).

Which bring us to another CSF: building collaborative relations with a solid and broad network, that includes diverse stakeholders - 'known strangers', academia, government agencies, policy makers, local communities, supply chain actors, stakeholders and NGOs. This network is an enabler for accessing funding, overcoming institutional barriers and creating legitimacy. It also provides access to knowledge and experience, including local traditions and community dynamics, as well as market, business, technologies, and project management tools and methods. Table 3 summarizes these results.

Additional CSFs include an entrepreneurial orientation, good communication and coordination, clear guidelines and high commitment, which can be obtained through a strong leadership. Additional enablers include technology, business incubators and funding bodies, legislative changes, policymakers' strong political support, and support from regional or national institutions (Navarro et al., 2018; Swagemakers et al., 2018).

\begin{tabular}{|c|c|}
\hline Main CSF and Enablers & How they contribute to social projects \\
\hline Innovation approach & $\begin{array}{l}\text { - Stimulates test and validation, bringing learning from failures } \\
\text { - Fosters error tolerance } \\
\text { - Includes participants with diverse backgrounds, knowledge and expertise }\end{array}$ \\
\hline $\begin{array}{l}\text { Human centric design } \\
\text { approach }\end{array}$ & $\begin{array}{l}\text { - Builds credibility, trust, acceptance, and awareness from the communities involved } \\
\text { - Develops human and social capital } \\
\text { - Develops win-win partnerships with stakeholders } \\
\text { - Stimulates value-based creation } \\
\text { - Enables the economic development of local community as business partners }\end{array}$ \\
\hline $\begin{array}{l}\text { Community Empowerment } \\
\text { through business } \\
\text { partnerships and solution co- } \\
\text { creation }\end{array}$ & $\begin{array}{l}\text { - Increases the chances of project continuity } \\
\text { - Develops entrepreneurial mindset } \\
\text { - Brings legitimacy to the project } \\
\text { - Builds trust with the community } \\
\text { - Stimulates collective learning } \\
\text { - Minimizes power distortions } \\
\text { - Provides a real understanding of local context and needs } \\
\text { - Enables the alignment of project scope with actual needs and limitations }\end{array}$ \\
\hline Stable financial resources & $\begin{array}{l}\text { - Promotes innovation } \\
\text { - Increases the chances of project continuity }\end{array}$ \\
\hline $\begin{array}{l}\text { Collaborative relations with } \\
\text { a solid and broad network }\end{array}$ & $\begin{array}{l}\text { - Provides easier access to all sort of resources: funding, knowledge (including local } \\
\text { traditions and community dynamic), skills, tools, and experience } \\
\text { - Creates legitimacy } \\
\text { - Increases the changes of overcoming institutional barriers }\end{array}$ \\
\hline Strong leadership & $\begin{array}{l}\text { - Provides entrepreneurial orientation } \\
\text { - Responsible for good communication and coordination } \\
\text { - Provides clear guidelines } \\
\text { - Promotes high commitment }\end{array}$ \\
\hline
\end{tabular}

Table 3. Main CSF and enablers for social projects.

\subsection{Barriers}


A context of deprivation, with tight resource constraints, where resources needed are externally sourced from actors with multiple perspectives, acts as a barrier for building credibility, trust and collaborative relations (Ahlberg et al., 2016; Chang et al., 2014). Social projects and enterprises face barriers to find the necessary resources and services - financial, technological, informational and human - more frequently than purely business commercial entities (Chang et al., 2014; Kulick, 2017). When investors provide support, they tend to put strong pressure towards compliance to principles of efficiency and short-term audit (Ochman, 2019), sometimes conflicting with the long-term goals and social values of these ventures.

Police makers and regional administration act as barriers if they are not willing to legislative changes, adapting rules and policies that impose constraints to the social projects - their innovative nature creating situations that are not fully regulated - imposing bureaucratic inefficiencies, lack of flexibility and top-down controls (Biygautane et al., 2020; Navarro et al., 2018; Raynor, 2019). Therefore, solutions to social problems often demand fundamental transformations in political, economic, and social systems (Alvord et al., 2004).

Finally, there are important barriers related to the underlying tensions in social ventures that lead to contradictions in their business model. These tensions include efficiency vs aid, break even profits vs consumer's economic power, and economy vs ethics (Sharma \& Jaiswal, 2018). Table 4 summarizes these results.

\begin{tabular}{|l|l|}
\hline Main Barriers & How they affect social projects \\
\hline Resource constraints & $\begin{array}{l}\bullet \text { Fosters competition for resources, making it difficult to build trust and collaborative } \\
\text { relations } \\
\bullet\end{array}$ \\
$\begin{array}{l}\text { - Brings the need to obtain resources from multiple partners, who might have } \\
\text { objectives that conflict with the long-term goals and social values of these ventures } \\
\text { Political or regulatory } \\
\text { Constraints }\end{array}$ & $\bullet$ Imposes bureaucratic inefficiencies, lack of flexibility and top-down controls \\
\hline $\begin{array}{l}\text { Business Model } \\
\text { Contradictions }\end{array}$ & $\begin{array}{l}\bullet \text { Creates internal tensions: efficiency vs aid; break even profits vs consumer's } \\
\text { economic power; economy vs ethics } \\
\bullet\end{array}$ \\
\hline
\end{tabular}

Table 4. Main barriers encountered in social projects.

\section{CONCLUSION}

This paper presented the CSF, enablers and barriers for social projects. It also analyzed their source of idea, types, targeted population, socio-economic context, geography, motivation, methodological approaches, and related research streams.

Contributions for the practice include the main challenges that will be encountered when implementing social projects, as well as enablers that will help in overcoming them. 
Contributions for the theory includes the simultaneous analysis of three different theoretical perspectives that have been applied in similar contexts.

Limitations include the research string and the subjectivity of data coding and analysis.

This paper is the initial effort of a research that aims at understanding how to configure Business Models that can be profitable while properly addressing BoP needs. Social projects were considered an initial step for companies and individuals that aim at developing social businesses. Next steps include a careful definition of constructs, and then the design and execution of case studies in Brazil.

\section{BIBLIOGRAPHY}

Ahlberg, B. M., Maina, F., Kubai, A., Khamasi, W., Ekman, M., \& Lundqvist-Persson, C. (2016). “A child, a tree": Challenges in building collaborative relations in a community research project in a Kenyan context. Action Research, 14(3), 257-275. https://doi.org/10.1177/1476750315607607

Alvord, S. H., Brown, L. D., \& Letts, C. W. (2004). Social Entrepreneurship and Societal Transformation: An Exploratory Study. The Journal of Applied Behavioral Science, 40(3), 260-282. https://doi.org/10.1177/0021886304266847

Austin, J., Stevenson, H., \& Wei-Skillern, J. (2006). Social and Commercial Entrepreneurship: Same, Different, or Both? Entrepreneurship Theory and Practice, 1042(2587), 1-22. https://doi.org/10.1111/j.1540$\underline{6520.2006 .00107 . x}$

Bevilacqua, C., \& Ou, Y. (2018). Place, relationships, and community-controlled capital: On ecosystem-based innovation towards an equitable competitive advantages distribution, the Boston Ujima project case. International Journal of Sustainable Development and Planning, 13(8), 1072-1089. https://doi.org/10.2495/SDP-V13-N8-1072-1089

Biygautane, M., Clegg, S., \& Al-Yahya, K. (2020). Institutional work and infrastructure public-private partnerships (PPPs): the roles of religious symbolic work and power in implementing PPP projects. Accounting, Auditing and Accountability Journal, 33(5), 1077-1112. https://doi.org/10.1108/AAAJ-042019-3982

Cazini, J., \& Frasson, A. C. (2011). Voices Project: Technological Innovations in Social Inclusion of People with Visual Impairment. In Special Issue ALTEC. J. Technol. Manag. Innov (Vol. 8). http://www.jotmi.org

Chang, J. Y. C., Benamraoui, A., \& Rieple, A. (2014). Stimulating learning about social entrepreneurship through income generation projects. International Journal of Entrepreneurial Behaviour and Research, 20(5), 417-437. https://doi.org/10.1108/IJEBR-10-2012-0111

Chou, D. C. (2018). Applying design thinking method to social entrepreneurship project. Computer Standards and Interfaces, 55, 1339-1351. https://doi.org/10.1016/j.csi.2017.05.001

Conrad, D. (2015). Education and Social Innovation: The Youth Uncensored Project-A Case Study of Youth Participatory Research and Cultural Democracy in Action. Canadian Journal of Education, 38(1), 1-25. $\underline{\text { www.cje-rce.ca }}$

Cox, V., Goethals, M., De Meulder, B., Schreurs, J., \& Moulaert, F. (2014). Beyond Design and Participation: The "Thought for Food" Project in Flanders, Belgium. Journal of Urban Design, 19(4), 412-435. https://doi.org/10.1080/13574809.2014.923742

Dacin, M. T., Dacin, P. A., \& Tracey, P. (2011). Social entrepreneurship: A critique and future directions. Organization Science, 22(5), 1203-1213. https://doi.org/10.1287/orsc.1100.0620

Daub, C. H., Hasler, M., Verkuil, A. H., \& Milow, U. (2020). Universities talk, students walk: promoting innovative sustainability projects. International Journal of Sustainability in Higher Education, 21(1), 97111. https://doi.org/10.1108/IJSHE-04-2019-0149 
De Filippi, F., Coscia, C., \& Cocina, G. G. (2017). Piattaforme collaborative per progetti di innovazione sociale. Il caso Miramap a Torino. TECHNE, 14, 219-226. https://doi.org/10.13128/Techne-20798

Erözçelik, A., \& Taşdizen, B. (2017). Designing on the Spot: Learning from the Social Design Projects in Gökçeada/Imbros Island. Design Journal, 20(sup1), $\quad$ S1751-S1764. https://doi.org/10.1080/14606925.2017.1352696

Galdini, R. (2020). Temporary uses in contemporary spaces. A European project in Rome. Cities, 96. https://doi.org/10.1016/j.cities.2019.102445

Gold, S., Hahn, R., \& Seuring, S. (2013). Sustainable supply chain management in "Base of the Pyramid" food projects-A path to triple bottom line approaches for multinationals? International Business Review, 22(5), 784-799. https://doi.org/10.1016/j.ibusrev.2012.12.006

Goyal, S., Kapoor, A., \& Sergi, B. S. (2020). Empowering rural women through shared value approach: Study of GNFC Neem Project in India. World Review of Entrepreneurship, Management and Sustainable Development, 16(4), 359-379. https://doi.org/10.1504/WREMSD.2020.109965

Gürdere Akdur, S., \& Kaygan, H. (2019). Social Design in Turkey through a Survey of Design Media: Projects, Objectives, Participation Approaches. Design Journal, 22(1), 51-71. https://doi.org/10.1080/14606925.2018.1560592

Hahn, R. (2009). The ethical rational of business for the poor - Integrating the concepts bottom of the Pyramid, sustainable development, and corporate citizenship. Journal of Business Ethics, 84(3), 313-324. https://doi.org/10.1007/s10551-008-9711-6

Karnani, A. (2007). The Mirage of Marketing to the Bottom of the Pyramid: How the Private Sector Can Help Alleviate Poverty. California Management Review, 49(4), 90-111. https://doi.org/10.2307/41166407

Kulick, G. (2017). Adding plus value to development aid projects through design strategy: experiences from Pakistan. Design Journal, 20(sup1), S411-S423. https://doi.org/10.1080/14606925.2017.1352939

London, T., Anupindi, R., \& Sheth, S. (2010). Creating mutual value: Lessons learned from ventures serving base of the pyramid producers. Journal of Business Research, 63(6), 582-594. https://doi.org/10.1016/j.jbusres.2009.04.025

Mair, J., \& Martí, I. (2006). Social entrepreneurship research: A source of explanation, prediction, and delight. Journal of World Business, 41(1), 36-44. https://doi.org/10.1016/j.jwb.2005.09.002

Malsch, F., \& Guieu, G. (2019). How to get more with less? Scarce resources and high social ambition: effectuation as KM tool in social entrepreneurial projects. Journal of Knowledge Management, 23(10), 1949-1964. https://doi.org/10.1108/JKM-12-2018-0745

Manzini, E., \& Rizzo, F. (2011). Small projects/large changes: Participatory design as an open participated process. CoDesign, 7(3-4), 199-215. https://doi.org/10.1080/15710882.2011.630472

Margarian, A. (2017). Tell me your financing and I tell you who you are. Social Enterprise Journal, 13(1), 5377. https://doi.org/10.1108/sej-08-2016-0040

Martin de Holan, P., Willi, A., \& Fernández, P. D. (2019). Breaking the Wall: Emotions and Projective Agency Under Extreme Poverty. Business and Society, 58(5), 919-962. https://doi.org/10.1177/0007650317745633

Morelli, N., Aguilar, M., Concilio, G., Götzen, A. De, Mulder, I., Pedersen, J., \& Torntoft, L. K. (2017). Framing Design to support Social Innovation: The Open4Citizens Project. Design Journal, 20(sup1), S3171-S3184. https://doi.org/10.1080/14606925.2017.1352823

Mulgan, G. (2006). The Process of Social Innovation. Innovations: Technology, Governance, Globalization, 1(2), 145-162. https://doi.org/10.1162/itgg.2006.1.2.145

Navarro, F., Labianca, M., Cejudo, E., De Rubertis, S., Salento, A., Maroto, J. C., \& Belliggiano, A. (2018). Interpretations of innovation in rural development. The cases of leader projects in Lecce (Italy) and Granada (Spain) in 2007-2013 Period. European Countryside, 10(1), 107-126. https://doi.org/10.2478/euco-2018-0007

Ochman, M. (2019). Financing Development Projects: An Approach by Civil Society Organizations. In Latin American Policy (Vol. 10). 
Olsen, M., \& Boxenbaum, E. (2009). Bottom-of-the-Pyramid: Organizational Barriers to Implementation. CALIFORNIA MANAGEMENT REVIEW, 51(4), 99-125.

Prahalad, C., \& Hart, S. (1999). Strategies for the bottom of the pyramid: creating sustainable development. Ann Arbor, 1001, 48109., January 1999, 1-26. http://www.bus.tu.ac.th/usr/wai/xm622/conclude monsanto/strategies.pdf

Prouska, R., \& Kapsali, M. (2020). The determinants of project worker voice in project-based organisations: An initial conceptualisation and research agenda. Human Resource Management Journal, July. https://doi.org/10.1111/1748-8583.12312

Rampasso, I. S., Siqueira, R. G., Martins, V. W. B., Anholon, R., Quelhas, O. L. G., Leal Filho, W., Lange Salvia, A., \& Santa-Eulalia, L. A. (2020). Implementing social projects with undergraduate students: an analysis of essential characteristics. International Journal of Sustainability in Higher Education. https://doi.org/10.1108/IJSHE-11-2019-0323

Raynor, K. (2019). Assembling an innovative social housing project in Melbourne: mapping the potential for social innovation. Housing Studies, 34(8), 1263-1285. https://doi.org/10.1080/02673037.2018.1535054

Reficco, E., \& Márquez, P. (2012). Inclusive Networks for Building BOP Markets. Business and Society, 51(3), 512-556. https://doi.org/10.1177/0007650309332353

Seuring, S., Brix-Asala, C., \& Khalid, R. U. (2019). Analyzing base-of-the-pyramid projects through sustainable supply chain management. Journal of Cleaner Production, 212, 1086-1097. https://doi.org/10.1016/j.jclepro.2018.12.102

Sharma, G., \& Jaiswal, A. K. (2018). Unsustainability of Sustainability: Cognitive Frames and Tensions in Bottom of the Pyramid Projects. Journal of Business Ethics, 148(2), 291-307. https://doi.org/10.1007/s10551-017-3584-5

Skjott Linneberg, M., \& Korsgaard, S. (2019). Coding qualitative data: a synthesis guiding the novice. In Qualitative Research Journal (Vol. 19, Issue 3, pp. 259-270). Emerald Group Publishing Ltd. https://doi.org/10.1108/QRJ-12-2018-0012

Souza Costa, J., Beatriz, A., Ribeiro Maia, G., Pinheiro De Freitas, A. R., Carlos, J., Da, L., Filho, S., Abreu Sá De Abreu, M., Correia, M., \& Filho, T. (2011). Social Technology as a Sustainable Public Policy: The Mandalla Project in Ceará. In Special Issue ALTEC. J. Technol. Manag. Innov (Vol. 8). http://www.jotmi.org

Swagemakers, P., Garcia, M. D. D., \& Wiskerke, J. S. C. (2018). Socially-inclusive development and value creation: How a composting project in Galicia (Spain) "Hit the Rocks.” Sustainability (Switzerland), 10(6). https://doi.org/10.3390/su10062040

Ubels, H., Haartsen, T., \& Bock, B. (2019). Social innovation and community-focussed civic initiatives in the context of rural depopulation: For everybody by everybody? Project Ulrum 2034. Journal of Rural Studies. https://doi.org/10.1016/j.jrurstud.2019.02.019

Viswanathan, M., \& Sridharan, S. (2012). Product development for the BoP: Insights on concept and prototype development from university-based student projects in India. Journal of Product Innovation Management, 29(1), 52-69. https://doi.org/10.1111/j.1540-5885.2011.00878.x

Zahra, S. A., Gedajlovic, E., Neubaum, D. O., \& Shulman, J. M. (2009). A typology of social entrepreneurs: Motives, search processes and ethical challenges. Journal of Business Venturing, 24(5), 519-532. https://doi.org/10.1016/j.jbusvent.2008.04.007 